\title{
A sustainable transportation: a literature study on park and ride in the Bandung metropolitan area
}

\author{
Annisa ${ }^{1,{ }^{*}}$, Herman $^{2}$, and Irvan Wiradinata ${ }^{3}$ \\ ${ }^{1}$ Department of Technic and Design, Institut Teknologi dan Sains Bandung, Lot-A1 CBD Kota \\ Deltamas, 17530, Indonesia \\ ${ }^{2}$ Department of Civil Engineering and Planning, Institut Teknologi Nasional Bandung, Jl. PH. H. \\ Mustofa No 23, Bandung, 40124, Indonesia \\ ${ }^{3}$ Intan Prima Kalorindo, PT, Jl. Tekno Raya B1-F, Bekasi, 17530, Indonesia
}

\begin{abstract}
Traffic congestion has been a major transportation problem in developing countries as private vehicles ownership has been increased dramatically each year. To solve this problem, local authorities need to construct new roads as well as parking infrastructure to meet consumer demand. Park and Ride can be regarded as a transportation management concept that can solve this demand. Park and Ride refers to a transportation management concept where travelers transit from a private transportation (i.e. motorcycle, car, bicycle, and other private transportation modes) to a public transportation system (i.e. bus, tram, heavy railway, mass rapid transport, and so forth). Park and Ride is believed to reduce private transportation in the metropolitan area of a city. In addition, Park and Ride should be located near a public transportation station in the suburban area. Hence, travelers can easily transit from their private vehicles in the suburban area to commute to urban area by using the public transportation system. This research will focus on the study of Park and Ride development in Bandung Metropolitan Area, Indonesia. Park and Ride, as explained earlier, may offer a solution to a sustainable transportation in Bandung Metropolitan Area.
\end{abstract}

\section{Introduction}

Transportation plays a major role in establishing urban sustainable development. In a rapidly increasing ownership of private vehicles in developing countries, such as Indonesia, a sustainable transportation management system has become a key necessity. In a modern sustainable transportation development, accessibility plays an important role as Tseu [1] and Rosli, et al. [2] explained. Moseley et al. [3] described accessibility as an opportunity for travelers to choose from a variety of transportation modes to get to their travel destination.

\footnotetext{
*Corresponding author: annisa@itsb.ac.id
} 
This research will examine the accessibility of transportation management system in the Bandung Metropolitan Area, Indonesia. The Bandung Metropolitan Area consists of Bandung City, Cimahi City, Bandung Regency, West Bandung Regency, and part of Sumedang Regency. Many travelers in the Bandung Metropolitan Area travel from suburban to urban area for many purposes, such as business, education, leisure, and many others. In the Bandung Metropolitan Area, many travelers prefer to use a private vehicle, such as motorcycle, and car for daily use. In terms of public transportation, the main public transportation modes used in this Metropolitan Area is an angkot (minibus), small-capacity public transport of 12 persons per vehicle. Having approximately 8.4 million inhabitants in this Metropolitan Area and limited access to sustainable public transportation, traffic congestion is therefore unavoidable, especially during the peak hours [4].

Several researchers have offered a solution to traffic congestion problems in Bandung Metropolitan Area [5, 6]. Asapa [5] mentioned that Park and Ride as part of heavy railway transportation system might offer the solution to travelers who live in a suburban area (i.e. Rancaekek and Cicalengka-both located in Bandung Regency). The Sub-National Development Planning Agency (Bappeda) [6] explained that to reduce traffic congestion in Bandung City, is by developing a transit-oriented development (TOD) system which is integrated to other public transportation modes. Park and Ride can be described as a traffic demand management system which aims to solve traffic congestion and carbon emission problem in the Metropolitan cities [7]. As explained in these previous researchers, Park and Ride may offer a solution to a problematic transportation system in Bandung Metropolitan Area. Furthermore, this research will focus on how Park and Ride can develop a sustainable transportation management system in Bandung Metropolitan Area.

The research question for this research is: "How to develop Park and Ride system in Bandung Metropolitan Area to obtain sustainable transportation?" Researchers will use the literature review approach for this research. Researchers will examine several journals, articles, and/or reports in regards to the Park and Ride system. This research aims to provide a suggestion as well as input to local authorities and stakeholders to obtain a sustainable transportation, in the hope that local authorities may develop the Park and Ride system in the Bandung Metropolitan Area. Additionally, the goal of this research is to examine the possibility of Park and Ride in Bandung Metropolitan Area. This research will examine previous studies concerning Park and Ride in Bandung Metropolitan Area and any other Metropolitan cities.

\section{Literature review}

A literature review was conducted in the early stage of this research. The purpose of the literature review was to learn from previous experiences in other cities that have already established a sustainable Park and Ride transportation management system. Important findings in the journals, articles, and reports are organized as the following.

\subsection{Sustainable transportation}

Sustainable transportation is closely related to sustainable urban development. Banister [8] argued that to obtain a sustainable urban development in the metropolitan city, one that needs to be considered is a traffic congestion problem in the urban area. In addition to that, Dijk, et al. [9] stated that big challenges to acquire a sustainable development in the metropolitan city are the traffic congestion as well as air emission problem. Banister [8] explains seven major issues as a result of urban transportation activities, such as: 1) congestion, 2) increasing air pollution, 3) traffic noise, 4) road safety, 5) degradation of urban landscapes, 6) use of space by traffic, and 7) global warming. Additionally, Gilbert 
and Tanguay [10] explained a sustainable transportation should meet such requirements: 1) accommodate basic needs of transportation, such as safety, healthy, and reliability, 2) economically beneficial, 3) offer several types of transportation mode, 4) reduce air pollution by using a renewable energy vehicle (i.e. electric vehicle), and 5) regulate and limit the carbon and air emission.

To solve the above-mentioned problems, many Metropolitan cities in developed countries have facilitated Park and Ride stations. Park and Ride are believed to be an answer to these problems. Park and Ride are argued to reduce traffic congestion and air emission in the urban area because travelers park their private vehicle in the suburban area $[11,12,13]$. Park and Ride are regarded as the solution to achieve low-carbon travel because travelers share their carbon emission by using the public transportation system [7].

\subsection{Park and ride in theory}

Historically, Park and Ride have been developed since the 1930s in the western countries [14]. Noel [14] also described Park and Ride as a transportation hub which connects travelers from their private vehicle (i.e. bicycle, motorcycle, and car) to their destination by using a public vehicle (i.e. minibus, bus, railway, tram, and so forth). In the United States, Park and Ride flourished in cities such as Washington D.C., San Francisco, Houston, Los Angeles, and Seattle. Between the 1970s and 1990s, many countries successfully adapted Park and Ride into their transportation management system, such as Canada, Calgary, Malaysia, Scotland, France, and Hongkong [11, 15].

Park and Ride can be regarded as a transportation mode that combines private and public transportation [16]. Aashto [17] described Park and Ride as a facility for private vehicle travelers who park their vehicle during the day and transit to public transportation to reach their destination. Liu [18] explained Park and Ride as a facility used by travelers to transit from their private transport to public transport to go from a suburban to an urban area. Zhu [19] stated that Park and Ride used by travelers as an option to move to public transportation from their private vehicle. Shen, et al. [7] explain that Park and Ride as a traffic demand management system which can solve urban traffic problems such as congestion and air pollution. To sum it up, Park and Ride can be concluded as a traffic management system which is developed for travelers to transit from a private vehicle to a higher occupancy vehicle to solve an urban traffic problem such as congestion as well as air pollution. To optimize the functionality of the Park and Ride system, two issues need to be taken into consideration: 1) location (Park and Ride shall be located in the suburban area), 2) sustainable public transportation in the urban area.

The rapid increase of the automotive industry has a consequence on the rising of private vehicle ownership in many Metropolitan Cities. As a result, traffic congestion and air pollution occur as a problem in these Metropolitan Cities. Shen, et al. [7] believe that an excellent Park and Ride management system could demise the effect of air pollution as well as solve the traffic problem. In addition to that, Dijk, de Haes, and Montalvo [9] argue that good sustainable development of transportation management system in the urban area will reduce air pollution because many travelers are switching from private vehicle to higher occupancy vehicle in the Park and Ride station. Good development and location of a Park and Ride station will encourage travelers' behavior to switch from a private to a public transportation system. Hence, traffic congestion in the urban area or city center of a Metropolitan city can be reduced [11, 12]. The purpose of Park and Ride is to connect suburban area and the city center of a Metropolitan area. Travelers may park their vehicle at the designated Park and Ride station, and continue to their destination using public transport system $[7,13]$. 
Many previous studies have explained the advantages of a Park and Ride management system. Cairns [13] stated that Park and Ride provide better access to transportation services. Karamycev and van Reeven [20] explained that Park and Ride help communities by reducing congestion on arterial roads. Islam, et al. [21] mentioned that Park and Ride could shift traveler's behavior by changing their transportation mode from a private to a public vehicle. Chen, et al. [22] explained that Park and Ride is a strategic solution for urban congestion and air pollution caused by vehicles. Moreover, Vuchic [23] argued that to build a Park and Ride station in the suburban is more economical than building it in the urban area due to its lower capital expenditure.

Previous studies also mention factors that influence travelers consideration to choose Park and Ride. Cornejo [11] described factors that influence travelers to choose a Park and Ride such as site location, parking availability, public transportation mode availability, and economic cost estimation. Also, Shen, et al. [7] explained that parking location, time spent searching for parking (transfer time), travel distance and public transportation mode availability are major factors for travelers to choose a Park and Ride station. Travelers choose a Park and Ride station due to its accessibility and economic reasons.

\subsection{Park and ride in practice}

Islam, et al. [21] explained that Park and Ride could be regarded as an important element in many western countries. Park and Ride also are described as a strategic congestion management solution which may also increase the economic profit for public transportation mode. This scheme will result in a more sustainable urban transportation system. In New York, the local authority states the importance of the Park and Ride system as evidence from its functionality and design [24]. Zhao [25] described in the United Kingdom the private vehicle ownership is above one vehicle per person. It is argued that Park and Ride may offer a solution as an effective travel mode from a suburban to an urban area in the United Kingdom. The study also explained the reasons whether or not travelers in the United Kingdom opt to choose Park and Ride. The major reason for using Park and Ride is for reducing travel time spent and fuel consumption. Also, Hole [26] explained the effective Park and Ride in the United Kingdom might be beneficial for the environment, because Park and Ride may significantly reduce air emission. Meanwhile, the key reasons for a nonPark and Ride are the availability of parking space, inconvenient transfer time, and high fares for parking in a Park and Ride station [25].

Olaru, et al. [27] argued that Park and Ride had become part of the urban landscape in Melbourne. In 2014, Chen [28] examined the traveler's behavior in the metropolitan city of Melbourne. It was revealed that there are several considerations for travelers in Melbourne to choose Park and Ride station, such as transfer time and fare. The transfer time can be explained as time spent for a private vehicle owner to locate a parking space in the Park and Ride station. Fare can be explained as the fare comparison between Park and Ride station in the suburban area and parking lot in the urban area. In this matter, parking spaces in the urban area of Melbourne offer more competitive fare than the Park and Ride station in the suburban area. Hence, many travelers in Melbourne opt to drive all the way to the urban area due to these two matters [28].

In the South East Asian region, Malaysia (Kuala Lumpur in particular) can be regarded as an early adapter for Park and Ride management system. Ho, et al. [29] explained several Park and Ride stations in Kuala Lumpur Metropolitan Area were over capacity as of the end of 2016. In Jakarta Metropolitan Area, many Park and Ride sites are located close to heavy railway stations and toll road [6]. Several concerns on Park and Ride travelers in the Jakarta Metropolitan Area have occurred, such as: 1) limited location of Park and Ride 
station, 2) limited parking lot availability, 3) lack of adequate facilities, 4) unregulated fare, 5) lack of connectivity to public transportation mode, and 6) lack of safety.

To sum it up, in practice Park and Ride did not always show its benefits. As several studies mentioned the disadvantages of Park and Ride. Chen, et al. [28] explained the main disadvantages of Park and Ride system is a limited choice of route and the split demand of travelers. Liu, et al. [30] argued that some Park and Ride sites might be unattractive to private vehicle traveler because of two main reasons: 1) the time spent to find the parking spot and 2) lack of good facilities. Truong and Marshall [31] determined that Park and Ride only transferred congestion from an urban to a suburban area. They also argued that carbonemission may only be mitigated in the urban area, while in the suburban area air pollution will continue to be a problem.

\section{Results and discussion}

Consisting of five cities, and inhabiting with 8.4 million inhabitants, the Bandung Metropolitan Area is considered as a very busy area in West Java, Indonesia. For this research, the urban and the suburban of the Bandung Metropolitan Area is explained as follows: the urban area consists of Bandung City, and the suburban area includes of Bandung Regency, West Bandung Regency, Cimahi City and small-scale of Sumedang Regency. Many people traveled across these cities using their private as well as public vehicles. This travel behavior often creates urban transportation problems such as congestion, air pollution, noise pollution, and so forth. Many congestions occur on the arterial roads which connect urban and suburban area in the Bandung Metropolitan Area such as on Jalan Raya Cibeureum, Jalan Terusan Buah Batu, Jalan Mohamad Toha, Jalan Raya Kopo, Jalan Raya Lembang, Jalan Raya Cipadung, and Bundaran Cibiru. Bappeda [6] reported that motorcycle dominated the type of private vehicle that traveled in these arterial roads. Data from the Badan Pusat Statistik (Central Statistical Agency) of Bandung [32] shows in 2016, approximately 20 million private vehicles (car type) traveled across the Bandung Metropolitan Area from the toll gate. In comparison, the Central Statistical Agency of Bandung [32] reveals the number of travelers who used the railway as a public transportation in 2016 was approximately 10 million.

These data show that the most popular transportation mode in the Bandung Metropolitan Area is a private transportation mode. Many travelers prefer to use a private transportation mode rather than a public one. Bappeda [6] argued that many travelers prefer to take private transportation mode due to the relatively short time spent on the road (shorter traveling time) when compared to the existing public transportation modes. It was revealed that traveling time using private vehicle is 25 minutes per day while using a public vehicle is 75 minutes per day [6]. One possible explanation regarding this matter is that travelers choose to travel from a suburban to an urban area of the Bandung Metropolitan Area using private vehicle is because shorter time spent compared to public transportation. Islam, et al. [21] described time as one of the key factors to determine travelers behavior in choosing a private vehicle to go to the urban area.

Moreover, it is suggested that, up until today, in Bandung Metropolitan Area there is a lack of public transportation hub or Park and Ride station in the suburban area. For instance, there are only six heavy railway stations (i.e. Cicalengka Station - Bandung Regency, Harupugur Station - Bandung Regency, Rancaekek Station - Bandung Regency, Cimekar Station - Bandung Regency, Cimahi Station - Cimahi City, and Padalarang Station - West Bandung Regency) located in the suburban area of the Bandung Metropolitan Area. A study that focused on showing the potential development of Park and Ride facilities based on heavy rail service in Rancaekek Station and Cicalengka Station (both stations are located in Bandung Regency) revealed a high demand for a parking space 
with a considerably high occupancy level of $81.5 \%$ [5]. It shows that the demand for Park and Ride station is considerably high in a suburban of Bandung Metropolitan Area. Hence, it is suggested that in the near future stakeholders should start to consider developing more transportation hub in the suburban area. Cornejo [11] explained location as one of the key success for Park and Ride management system. Building Park and Ride station in a strategic suburban area will encourage travelers behavior to switch from a private to a public transportation system. The Bandung Metropolitan Area's local authorities have planned to construct several Park and Ride stations in the transit-oriented development (TOD), such as Padalarang, Cimahi, Soreang, Lembang, Tanjungsari, Majalaya, Gedebage, Ujung Berung, and Leuwi Panjang [6].

Researchers believed to have a sustainable transportation system, four requirements need to be met, and these are accessibility, safety, environmentally friendly, and affordable $[1,2,3.10]$. Accessibility refers to adequate resources for travelers to choose from, in order to go to their destination. As one of the main public transportation used in Bandung City currently, Angkot (minibus) has an inadequate route management system. For instance, the route of this public transportation system mode is not straightforward and not well connected. Bappeda [6] described that the average time for using public transportation in Bandung City is 75 minutes a day, compared to 25 minutes by a private vehicle. Also, there is no consideration at all for time spent when travelers are using this mode, as Angkot drivers tend to stop for a long time to get more commuters [33]. Safety refers to the safety condition consistently. For instance, many road accidents that occur in Bandung City involve public transportation system such as Angkot. Wicaksono [33] revealed that many Bandung City Angkot drivers violate traffic regulations which lead to accidents. Environmentally Friendly refers to the limits of emissions and waste within the planet's ability to absorb them.

Table 1. Public Transportation Occupancy Level in Bandung City in 2013 [6, 32, 33].

\begin{tabular}{|c|c|c|}
\hline Type of public transport & Number of fleet & Occupancy level \\
\hline Angkot (Mini Bus) & 5521 & $4.7 \%$ \\
\hline Bus & 3166 & $26 \%$ \\
\hline
\end{tabular}

Table 1 shows that Angkot has the occupancy level as low as 4.7\%. Meanwhile, Bus has $26 \%$ level of occupancy but with a lower number of the fleet. Lower occupancy level means more air emission spread and noise created. Affordability refers to reasonably priced and economical. For instance, in Bandung City, the average price for a single trip will cost as low as USD 30 cents [6] which can be regarded as an affordable price. However, due to inadequate connectivity, travelers may change public transportation several times before reaching their final destination. This problem will affect the cost of using public transportation as in Bandung City, and travelers need to pay every time they use a public transportation system because Bandung City does not have well-integrated public transport. To sum up, it is argued that Bandung City has not qualified to be regarded as a city with a sustainable transportation system. Therefore, it is believed that to have a park and ride system in the suburban area, one consideration should be the maturity of the transport management system in the urban area. It is suggested that Bandung City needs to improve the public transportation system that can offer good accessibility and wide interconnecting network, consistent safety standard, increase the occupancy level to have a better environmental effect, and create a well-integrated public transportation mode to lower the price for travelers. 


\section{Conclusions}

This research examined the study literature of Park and Ride management system. Findings show Park and Ride offers a solution for transportation matters such as congestion and air emission. This research also identified that Park and Ride concept would not work without a mature public transportation management system in the urban area of the metropolitan city. In the case of Bandung Metropolitan Area, the inadequate public transportation management system in the urban area (Bandung City) has been a major roadblock to allow for the full benefits of Park and Ride to take effect, that is ultimately to reduce traffic congestion and air emission.

This research has several limitations, such as this research only focused on the public transportation system in Bandung City, lack of quantitative data on the behavior of travelers in the Bandung Metropolitan Area, and lack of comprehensive data on transportation mode used in this area. This limitation is present due to the limited time spent for conducting this research. Furthermore, researchers suggest that for future researches, the following shall be noted: future research shall assess several metropolitan cities in Indonesia (i.e. Makasar, Medan, and Surabaya) and compare the results, provide quantitative behavioral data for these future research, and provide an extensive data on transportation mode used.

\section{References}

1. L. Tseu, Fourth Sabah-Sarawak Env. Conv (Malaysia, 2006)

2. N.S. Rosli, S. Adnan, S.A. Alyia, F.D. Ismail, A.A.K. Hamsa, EAROPH (Malaysia, 2012)

3. M.J. Moseley, R.G. Harman, O.B. Cole, M.B. Spencer, Rural transport and accesibility (University of East Anglia, UK, 1977)

4. J. Jupri, A. Mulyadi, Seminar Nasional Geografi (UMS, Solo, 2017)

5. A.G. Asapa, JRCP 25, 157 (2014)

6. Bappeda, Review masterplan dan penyusunan rancangan peraturan wilayah transportasi kota Bandung (Bappeda Bandung, 2013)

7. X. Shen, F. Chen, B. Su, Q. Chen, J. Yao, AIME 9 (2017)

8. D. Banister, Transport Rev. 20, 113 (2000)

9. M. Dijk, J. de Haes, C. Montalvo, J. Transp. Geogr 30, 149 (2013)

10. R. Gilbert, H. Tanguay, Sustainable transportation performance indicators project: brief review of some worldwide activity and development of an initial long list of indicators (Centre for Sustainable Transportation, Mississauga, 2000)

11. L. Cornejo, S. Perez, R.L. Cheu, S. Hernandez, IJTST 3, 1 (2014)

12. M. Duncan, JPER 30, 162 (2010)

13. M.R. Cairns, J. Transp. Geogr. 6, 295 (1988)

14. E.C. Noel, J. Urban Plan. D. ASCE 114, 2 (1988)

15. E. Buchari, Proc. EACEF-5 125, 512 (2015)

16. G. Parkhurst, Transp. Policy 2, 15 (1995)

17. AASHTO, Geometric Design Guide for Transit Facilities on Highways and Streets (AASHTO, America, 2002)

18. H.Z. Liu, Research on $P \& R$ system based on rail transit in metropolitans (Changsa University of Science and Technology, China, 2009) 
19. C. Zhu, B. Jia, L. Han, Z. Gao, Discrete Dyn. Nat. Soc. (2013)

20. V. Karamychev, P. van Reeven, Reg. Sci. Urban Econ. 41, 455 (2011)

21. S.T. Islam, Z. Liu, M. Sarvi, T. Zhu, Math. Probl. Eng. (2015)

22. X. Chen, Z. Liu, D. Hua, I. Kim, Transportation Research Proc. 21, 79 (2016)

23. V.R. Vuchic, Urban transit: operations, planning, and economics (New Jersey, 2005)

24. J.H. Veras, W.F. Yushimito, F.A. Vera, J.J. Reilly, Transportation Res. Part B: Methodological 46, 949 (2012)

25. X. Zhao, Y. Li, H. Xia, J. Adv. Mech. Eng. 9, 1 (2017)

26. A.R. Hole, Transport Policy 11, 355 (2004)

27. D. Olaru, B. Smith, J.C Xia, C. Chen, T. Lin, Ticket to ride: factors affecting park-andride travel in Perth WA (AET Papers Repository, Transport Research Society, 2014)

28. X.Y. Chen, Z. Liu, S. Islam, W. Deng, Park-and-ride network design in a bi-modal transport network to prompt public transport mode share (ICVRAM, 2014)

29. P.W. Ho, S.M.S. Ismail, MATEC Web of Conference 103 (2017)

30. W. Liu, H. Yang, Y. Yin, J. Adv. Transport 48, 655 (2014)

31. L.C Truong, W.E Marshall, J. Transp. Res. Rec. 2419, 109 (2014)

32. Statistics of Bandung City, Bandung city in figures (2015)

33. R. Wicaksono, M. Pasaribu, Product Design 4 (2015) 